\title{
Removal of Copper Ions from Aqueous Solution Using Liquid Surfactant Membrane Technique
}

\author{
Huda M. Salman and Ahmed Abed Mohammed
}

Environmental Engineering Department, College of Engineering, University of Baghdad, Baghdad, Iraq

\begin{abstract}
Extraction of copper $(\mathrm{Cu})$ from aqueous solution utilizing Liquid Membrane technology (LM) is more effective than precipitation method that forms sludge and must be disposed of in landfills. In this work, we have formulated a liquid surfactant membrane (LSM) that uses kerosene oil as the main diluent of LSM to remove copper ions from the aqueous waste solution through di- (2-ethylhexyl) phosphoric acid - D2EHPA- as a carrier. This technique displays several advantages including one-stage extraction and stripping process, simple operation, low energy requirement, and. In this study, the LSM process was used to transport Cu (II) ions from the feed phase to the stripping phase, which was prepared, using $\mathrm{H}_{2} \mathrm{SO}_{4}$. For LSM process, various parameters have been studied such as carrier concentration; treat ratio (TR), agitating speed and initial feed concentration. After finding the optimum parameters, it was possible to extract $\mathrm{Cu}$ up to $95 \%$ from the aqueous feed phase in a single stage extraction.
\end{abstract}

Keywords: Copper, D2EHPA, Extraction, Surfactant, Liquid membrane

Received on 06/04/2019, Accepted on 28/05/2019, published on 30/09/2019

https://doi.org/10.31699/IJCPE.2019.3.5

\section{1- Introduction}

Increased use of metals and chemicals in process industries has resulted in the generation of large quantities of effluent that contain high levels of toxic heavy metals and their presence poses disposal problems due to their non-degradable and persistent nature. The most toxic metals are aluminum, cobalt, chromium, iron, cadmium, nickel, zinc, copper, lead and mercury, based on World Health Organization (WHO) [1]-[3]. The main industries that add water pollution by chromium are leather tanning, mining, electroplating, textile dyeing, coating operations, aluminum conversion, and pigments. Removal of ions from their effluents has assumed of a higher importance in the recent past due to the decreasing availability of natural resources and the increasing pollution in the environment [4]-[6].

The elimination of copper $(\mathrm{Cu})$ from aqueous solutions requires an efficient system for environmental reasons (toxic ions when it above WHO limits). There is a general concern to minimize the liquid effluents containing dangerous metals. A traditional method to remove $\mathrm{Cu}$ from solutions is the solvent extraction method. In this technique, a well-established $\mathrm{Cu}$ extract should be used, such as diketones or hydroxytoxics [7].

LIX acid (Cognis) and di- (2-ethylhexyl) phosphoric acid (D2EHPA), etc, the use of this carrier in the recovery of $\mathrm{Cu}$ is well indicated elsewhere [8]-[11].
Liquid Surfactant Membrane (LSM) has been considered as an alternative to the solvent extraction for separating solutes, like phenols, biochemical products, and metal pollutants [2], [12]-[19].

LSM is a triple dispersion method, where a primary emulsion (water/oil or oil/water) is dispersed in a feed phase (E) to be treated. The liquid membrane comprises from three phases i) internal ii) external, and iii) organic phase. The organic phase contains a diluent, an emulsifier to stabilize the emulsion, and an extractant in the case of separation of metal ions [10].

During the mixing between the feed phase (E) and emulsion (organic + internal), the solute is transported through the membrane into the stripping phase droplets and is concentrated [20].

After extraction, the emulsion is separated from the raffinate phase and the demulsified of the emulsion is usually performed by applying high voltage or heat. LSM exhibit several advantages, such as re-extraction in a single stage, large specific surface area for extraction, simultaneous extraction, and the requirement of an expensive extractant in small quantities [10], [21], [22].

The objective of this work was to check the potential of a liquid surfactant membrane (LSM) for the extraction of copper ions from the feed solution. 
Despite, studies in this field, the study investigate various experimental parameters, like extractant concentration, treatment ratio, agitation rate, and initial feed concentration were examined, to identify the best conditions, which would give the greatest performance of the LSM.

\section{2- Experimental Protocols}

\subsection{Reagents}

The phosphorus acid di- (2-ethylhexyl) (D2EHPA) functioned as a shuttle and Sorbitan monooleate (Span 80 $\mathrm{C}_{24} \mathrm{H}_{44} \mathrm{O}_{6}$ ) was the nonionic emulsifier, both reagents were supplied by Sigma-Aldrich (Merck, Darmstadt, Germany). Kerosene supplied by the Southern Oil Company (SOC) (Al Basra-Iraq) used as a diluent, while the sulphuric acid $\left(\mathrm{H}_{2} \mathrm{SO}_{4}\right)$ was the eliminating agent and was obtained from the factory producing acids and bases (Babylon, Iraq). Copper solutions were prepared from copper nitrate (Chemical Company, Co., Ltd. Korea).

\subsection{Procedure}

The experimental work consists of four parts: preparation of the emulsion as a first step, preparation of stock solution, then running the extraction process and finally the demulsification for emulsion. Fig. 1 illustrates the procedure of LSM in this paper.

\section{a. Emulsion preparation}

Mixing certain volume of kerosene, Span80, and D2EHPA at homogenizer (SR30 digital homogenizer, model: $670 / 340 \mathrm{~W}, 10-2000 \mathrm{ml}, 3000-27000 \mathrm{rpm})$ speed of $17500 \mathrm{rpm}$ to get the oil phase. The sulphuric acid $\left(\mathrm{H}_{2} \mathrm{SO}_{4}\right)$ solution as a stripping agent was added dropwise to the oil phase until the desired volume ratio of oil solution to stripping solution was obtained. The solution was stirred continuously for $10 \mathrm{~min}$ to obtain a stable Water/Oil LSM.

\section{b. Feed phase preparation}

This phase was prepared by adding distilled water (conductivity, $1 \mu \mathrm{s} / \mathrm{m}$ ) to $\mathrm{Cu}\left(\mathrm{NO}_{3}\right)_{2}$ (solid form) to get the required concentrations (200 ppm) of copper and then adding some drops of the sulphuric acid to reach $\mathrm{pH}$ equal 4.

\section{c. Extraction}

All experiments were performed at a temperature of $25 \pm 1^{\circ} \mathrm{C}$. The prepared emulsion (Error! Reference source not found.) was added to a specific volume of feed solution. The production of Water/Oil/Water double emulsions was obtained from stirring the contents by a digital stirrer (12700 rpm) for $12 \mathrm{~min}$. Syringe and filter syringe was used to draw external solution (E) and then analyzed it by AAS (atomic absorption spectrophotometry).

The resulted solution was allowed to separate to an emulsion (Water/Oil) and an external solution (E) by gravity in a separation funnel for 24 hours. After twophase separation, the external phase was drawn and the concentration of $\mathrm{Cu}$ in the internal phase was analyzed using AAS (Atomic Absorbtion Spectrophotometer). The $\mathrm{Cu}$ (II) ions remain in membrane phase can be calculated by mass balance. To know the significant variables relating to the extraction of $\mathrm{Cu}$, the extractant concentration, initial $\mathrm{Cu}$ concentration, treat ratio (TR), and stirring speed were varied to observe their effects on $\mathrm{Cu}$ extraction.

\section{d. Demulsification of the emulsion}

After the extraction experiment, the loaded emulsion was broken using a hot plate magnetic stirrer $\left(70{ }^{\circ} \mathrm{C}\right.$ for $43 \mathrm{~min}$ ) into the internal $\mathrm{Cu}$ concentrated phase and the organic phase. The internal phase (I) was analyzed and after that determining $\mathrm{Cu}$ concentration.

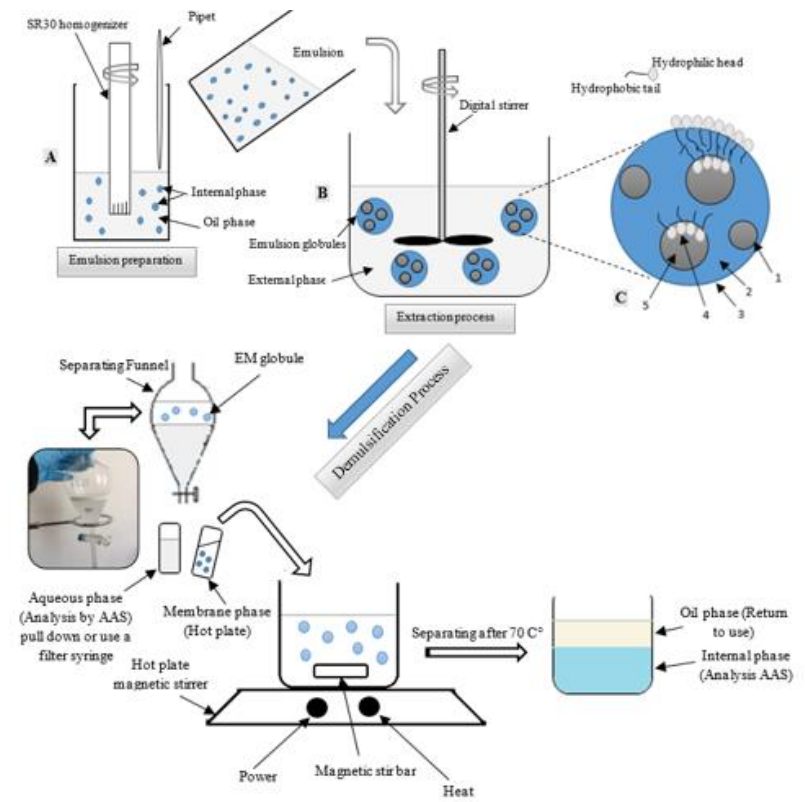

Fig. 1. LSM technique,: (1) droplets, (2) organic phase, (3) globules, (4) emulsifier and (5) internal phase and $\mathrm{Cu}$

\subsection{Extraction mechanism in the ELM system}

The prepared emulsion (sec. $2.2 \mathrm{~A}$ ) was transferred to the external phase containing a certain concentration of copper ions at $\mathrm{pH} 4$ (adding some drops of $0.2 \mathrm{M}$ $\mathrm{H} 2 \mathrm{SO} 4)$.

A digital mixer was utilized to agitate the solution for 0-12 minutes. The extraction and stripping reactions of the copper ions are elucidated in equation 1 and 2 .

Where: $\mathrm{RH}$ refers to the protonated form of an extracting (D2EHPA in this paper) [23]. D2EHPA structure is revealed in Fig. 2 [24], [25]. 


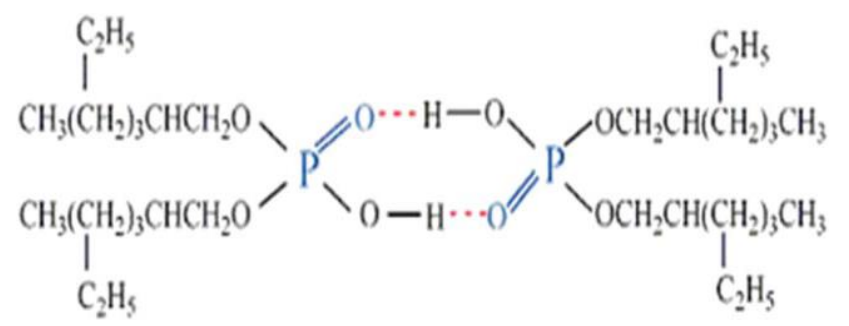

Fig. 2. Depicts the structure of D2EHPA

Extraction reaction of the copper ions:

$\mathrm{Cu}_{(s)}^{+2}+2(R H)_{(L)} \rightarrow P b R_{2}(R H)_{2}+2 H^{+}$

Stripping reaction of the copper ions:

$$
\mathrm{CuR}_{2}(\mathrm{RH})_{2}+2 \mathrm{H}^{+} \rightarrow \mathrm{Cu}_{(S)}^{+2}+2(\mathrm{RH})_{2(L)}
$$

Equation (1) denotes the reaction at the membrane (O) external (E) interface, while equation (2) shows the reaction where the copper ions are stripped at the oil $(\mathrm{O})$ internal (W) interface. The $\mathrm{Cu}$ (II) ions transfer by an extracting from the external to the internal phase is explained in Fig. 3. The extraction percentage (E\%) is found based on the equation (3) :

$\mathrm{E} \%=\frac{\mathrm{C}_{\text {in }}-\mathrm{C}_{\text {out }}}{\mathrm{C}_{\text {in }}} \times 100 \%$

Where $C_{i n}$ is the initial copper concentration in the external phase, and $\mathrm{C}_{\text {out }}$ is the copper ion concentration post the extraction stage.

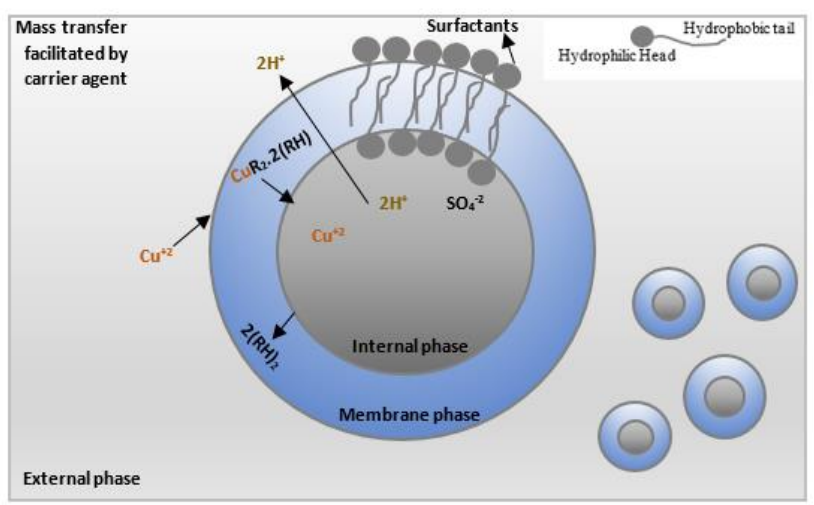

Fig. 3. Depicts the transfer mechanism of LSM

\section{3- Results and Discussion}

3.1. Effect of Changes in Carrier Concentration on Copper Removal Efficiency

This paragraph presented in Fig. 4 as expected, as soon as the mixing began, the first $0.5 \mathrm{~min}$ the extraction efficiency increased due to the carrier's effectiveness in carrying the copper ions as well as increasing the shuttle
D2EHPA concentration from $6 \%-8 \%(\mathrm{v} / \mathrm{v})$ provides only $2 \%$ increase in the quantity extracted using LSM.

At $10 \%$ D2EHPA, the $\%$ E slightly decreased. It should be noted that under optimum conditions in the copper extraction from nitrate solution it was observed that D2EHPA concentration in the membrane phase in the range of $2 \%(\mathrm{v} / \mathrm{v})$ to $4 \%(\mathrm{v} / \mathrm{v})$ decreased the rate of extraction of copper as observed by [2], [23]. From an economic point of view, an enhancement of $2 \%$ is very low, so $6 \%$ D2EHPA is applied in the experiments.

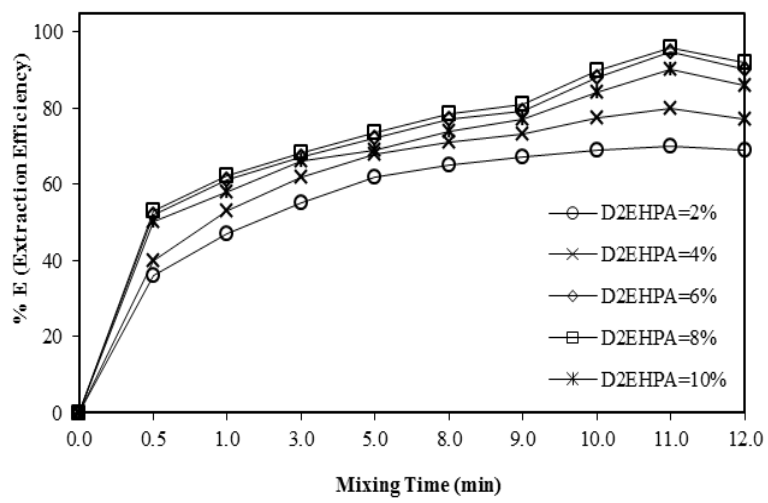

Fig. 4. Effect of D2EHPA concentration on the $\mathrm{Cu}$ extraction at optimal conditions, using LSM $(\mathrm{O} / \mathrm{I}=1 / 1$, span $80=4 \mathrm{v} / \mathrm{v} \%, \mathrm{H}_{2} \mathrm{SO}_{4}=0.5 \mathrm{M}$, feed concentration $\approx 200$ $\mathrm{mg} / \mathrm{L}, \mathrm{pH}=4, \mathrm{TR}=1: 10$, mixing speed=250 rpm)

\subsection{Effect of Changes of Stirring Speed on the Copper Removal Efficiency}

Another parameter affecting extraction to a large extent was found to be stirring speed, and it has been studied in the range 150 to $550 \mathrm{rpm}$ using LSM1 and shown in Fig. 5.

As the stirring speed increased from 150 to $250 \mathrm{rpm}$, the removal of copper increased from $82 \%$ to $94.7 \%$ in 11 min time using LSM. This was due to the small size of the globules (SSG) that were formed by shear force from the impellers of the stirrer, which provided more interfacial surface area for effective mass transfer. Above $11 \mathrm{~min}$, no copper was detected in the external phase due to membrane breakage. However, as the stirring rate was increased to $300 \mathrm{rpm}$, more shear was introduced into the emulsion and external phase, which promotes emulsion breakage.

For lower agitating speed, the interfacial contact area and mass transfer between the external phase and emulsion decreased due to the larger size of the emulsion. A $250 \mathrm{rpm}$ was suitable for satisfactory extraction percentage. After 250-rpm extraction, percentage starts to decline. Further increase in the mixing speed resulted in a break of liquid surfactant membranes leading to an outflow of extracted lead into the external phase.

This is because of a higher mixer speed which beyond limits generally results in higher water transport into the inner strip phase causing the membrane to swell [26], [27]. Therefore, $250 \mathrm{rpm}$ was chosen as the optimum mixing speed for extraction of $\mathrm{Cu}$ (II). 


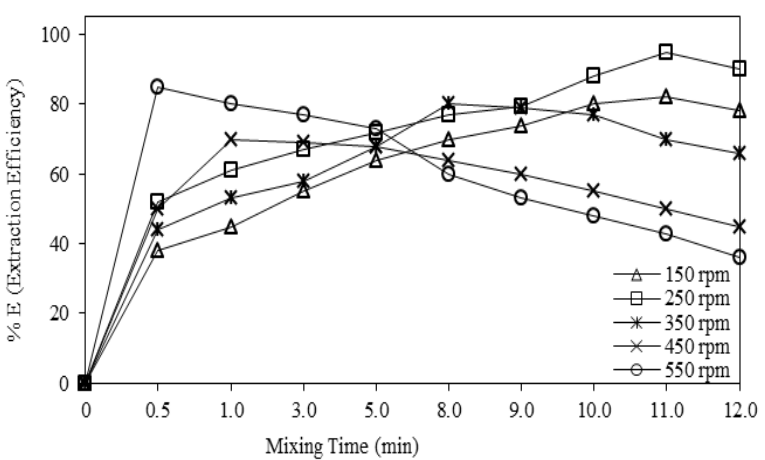

Fig. 5. Effect, of stirring speed on a rate of copper extraction using LSM

\subsection{Effect of Changes of Treat Ratio (TR) on the Copper Removal Efficiency}

The treat ratio in an LSM extraction is the ratio of the emulsion phase to feed phase. Increasing TR generally leads to an increase in the loading capacity, and the rate of extraction. This case happened due to existence increment in emulsion volume and correspondingly an increase in D2EHPA, and $\mathrm{H}_{2} \mathrm{SO}_{4}$ [28], [29].

Fig. 6 illustrates the effect of TR on the copper extraction from copper nitrate solutions using LSM.

As TR increased there was an increase in the efficiency of, this occurs when this ratio increased from 1:15 to $1: 10$. This pattern could be recognized from a possible increase in globule size distribution due to the increased hold-up of the emulsion.

Sengupta et al. (2006) have noted a strong decline in the extraction percentage of silver ions when TR was increased from 1:6 to 1:4 due to increased globule size distribution at larger emulsion hold-ups.

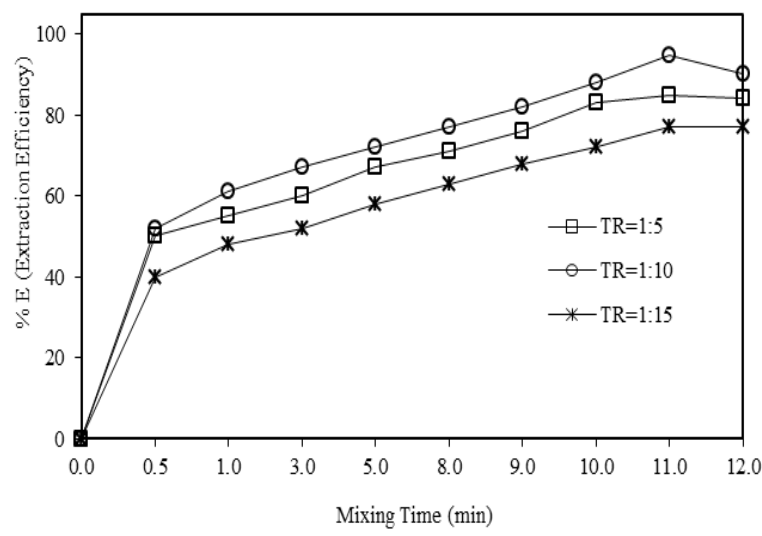

Fig. 6. Effect of (TR) on the Cu-extraction by LSM

The formation of LG (larger globules) reduces the areas of the outer surface and will increase the effective length of the diffusion pathways among the globule, causing a low rate of $\mathrm{Cu}$ removal.
Treat ratios of 1:15, 1:10 and 1:5 indicate a considerable increase in extraction capability at what time TR increased from $1: 15$ to $1: 10$, due to the increase in emulsion retention, the distribution of the size of globules tended to change towards $L G$ with a consequent reduction in the rates.

\subsection{Effect of Changes of Initial Copper Concentration on Copper Removal Efficiency}

The effect of initial $\mathrm{Cu}$ (II) ions concentrations in the feed on the rate of copper extraction, was investigated using emulsions having $\mathrm{O} / \mathrm{I}=1 / 1, \operatorname{span} 80=4 \mathrm{v} / \mathrm{v} \%$ of the organic phase and $\mathrm{H}_{2} \mathrm{SO}_{4}=0.5 \mathrm{M}, \mathrm{D} 2 \mathrm{EHPA}=6 \%(\mathrm{v} / \mathrm{v})$. The initial $(\mathrm{pH})$ and (TR) were kept at 4 and 1:10 respectively. Extraction results are displayed in Fig. 7 that is a plot of the change in copper concentration in the feed phase with time.

The pattern of copper loading in LSM along with a quantitative assessment of the amount of copper stripped in the internal stripping phase of the emulsion, after a 12 min contact between the feed and the LSM, for initial feed concentration variations, is presented in Fig. 8.

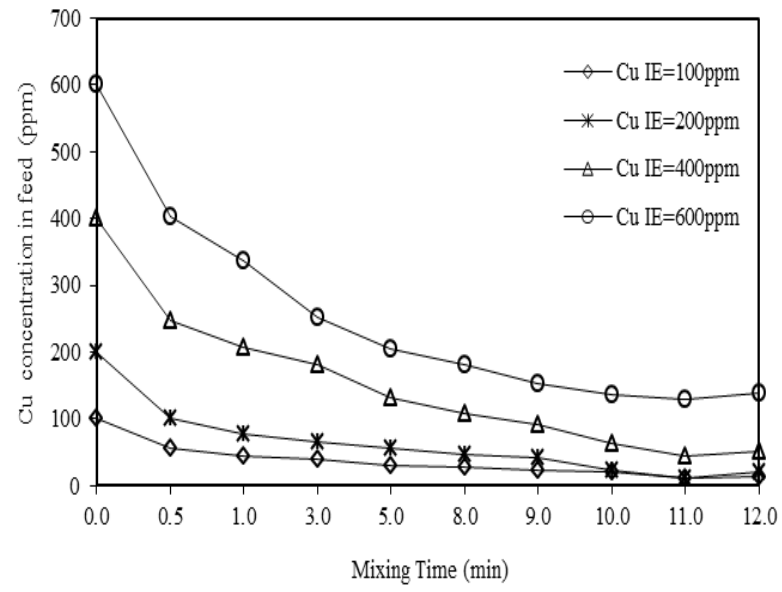

Fig. 7. Effect of initial-feed concentration on rate of copper extraction using LSM $(\mathrm{O} / \mathrm{I}=1 / 1$, span $80=, 4 \mathrm{v} / \mathrm{v} \%$, $\mathrm{H}_{2} \mathrm{SO}_{4}=, 0.5 \mathrm{M}, \mathrm{D} 2 \mathrm{EHPA}=6 \%$, feed concentration $\approx 200$ $\mathrm{mg} / \mathrm{L}, \mathrm{pH}=4, \mathrm{TR}=1: 10$, mixing speed=250 rpm). $(\mathrm{Cu} \mathrm{IE}$, initial-concentration of copper, in the external phase)

It was observed that as the initial feed concentration increased, the extent of copper extraction into LSM also increased.

When $\mathrm{Cu}$ loading was low most of the $\mathrm{Cu}$ extracted in the membranes got stripped in the internal phase of the membranes.

However, at high copper loadings, the amount of copper stripped in the internal phase of the LSMs did not increase substantially; hence most of the copper extracted by the LSMs was retained in the membrane phase[4], [21], [22]. 


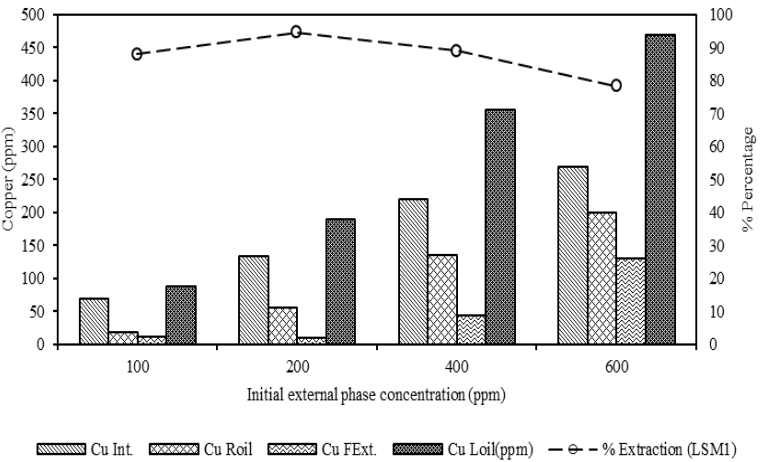

Fig. 8. Copper extraction, stripping patterns in LSM (Int., internal phase; Roil, Retained in the oil phase; FExt, final concentration in the external phase

The low percentage of $\mathrm{Cu}$ stripping could be recognized from the slow stripping kinetics as well as the diffusional effects that play an important role in further slowing down the stripping rates. High values of $\mathrm{Cu}_{\mathrm{IE}}$ (Initial copper concentration) lead to greater copper loadings in the LSMs causing, quick saturation of the peripheral internal phase droplets in the emulsion necessitates deeper penetration of the $\mathrm{Cu}-\mathrm{D} 2 \mathrm{EHPA}$ complex within the emulsion globules to get stripped.

\section{4- Conclusions}

Extraction of copper $\mathrm{Cu}$ (II) from an aqueous phase was studied utilizing a liquid surfactant membrane (LSM). The membrane was composed of D2EHPA dissolved in kerosene and span80 as a solvent as an emulsifier respectively.

Sulfuric acid $\left(\mathrm{H}_{2} \mathrm{SO}_{4}\right)$ was utilized as the stripping solution. The optimum conditions for $\mathrm{Cu}$ extraction are: (a) $6-8 \%(\mathrm{v} / \mathrm{v})$ D2EHPA concentration, (b) $4 \%$ (v/v) span80 concentration, (c) $0.5 \mathrm{M} \mathrm{H}_{2} \mathrm{SO}_{4}$ concentration in the internal phase, (d) 1:1 the ratio of internal phase to membrane phase, (e) acidity in external phase is 4 ; (f) external phase volume to membrane volume $1 / 10$, (g) extraction time, 11 minutes; and (h) agitating speed, 250 rpm.

The results also showed many parameters, stirring speed, the D2EHPA concentration, feed concentration and treating ratio, are very important in the extraction of $\mathrm{Cu}$, (2) the extraction efficiency (E) of $\mathrm{Cu}$ is $95 \%$ at $11 \mathrm{~min}$., (3) at higher agitating speed of the water/oil/water emulsion produces small emulsion droplets, consequently increases the interface area of the carrier/Cu reaction.

However, it is necessary this paper considered a maximum limit $(250 \mathrm{rpm})$ to increase the extraction efficiency, (4) the results showed that the LSM method is a beneficial process to remove $\mathrm{Cu}$ from aqueous solution.

\section{References}

[1] H.A. Hegazi, Removal of heavy metals from wastewater using agricultural and industrial wastes as adsorbents, HBRC Journal 9 (2013) 276-282.

[2] A.A. Mohammed, H.M. Selman, Liquid surfactant membrane for lead separation from aqueous solution: Studies on emulsion stability and extraction efficiency, Journal of Environmental Chemical Engineering 6 (2018) 6923-6930.

[3] A. H. Algureiri and Y. R. Abdulmajeed, "Removal of Heavy Metals from Industrial Wastewater by Using RO Membrane", ijcpe, vol. 17, no. 4, pp. 125-136, Dec. 2016.

[4] D. Lu, Y. Chang, W. Wang, F. Xie, E. Asselin, D. Dreisinger, Copper and cyanide extraction with emulsion liquid membrane with LIX 7950 as the mobile carrier: part 1, Emulsion stability, Metals 5 (2015) 2034-2047.

[5] M. Hasan, Y. Selim, K. Mohamed, Removal of chromium from aqueous waste solution using liquid emulsion membrane, Journal of hazardous materials 168 (2009) 1537-1541.

[6] A.M. Hochhauser, E. Cussler, CONCENTRATING CHROMIUM WITH LIQUID SURFACTANT MEMBRANES, AIChE Symposium Series, American Institute of Chemical Engineers, 1975, pp. $\underline{136-142 .}$

[7] J. Rydberg, C. Musikas, G.R. Choppin, Principles and practices of solvent extraction, M. Dekker New York1992.

[8] K. Kongolo, M. Mwema, A. Banza, E. Gock, Cobalt and zinc recovery from copper sulphate solution by solvent extraction, Minerals Engineering 16 (2003) 1371-1374.

[9] S.-Y.B. Hu, J.M. Wiencek, Copper-LIX 84 extraction equilibrium, Separation Science and Technology 35 (2000) 469-481.

[10] S. Abdel-Halim, A. Shehata, M. El-Shahat, Removal of lead ions from industrial waste water by different types of natural materials, Water Research 37 (2003) 1678-1683.

[11] E.A. Fouad, Zinc and Copper Separation through an Emulsion Liquid Membrane Containing Di-(2Ethylhexyl) Phosphoric Acid as a Carrier, Chemical Engineering \& Technology: Industrial ChemistryPlant Equipment-Process Engineering-Biotechnology 31 (2008) 370-376.

[12] P.F. Correia, J.M. de Carvalho, Recovery of 2chlorophenol from aqueous solutions by emulsion liquid membranes: batch experimental studies and modelling, Journal of Membrane Science 179 (2000) 175-183.

[13] A.A. Mohammed, H.M. Selman, Extraction of Lead Ions from Aqueous Solution by CO-Stabilization Mechanisms of Magnetic Fe2O3 Particles and Nonionic Surfactants in Emulsion Liquid Membrane, 
Colloids and Surfaces A: Physicochemical and Engineering Aspects (2019).

[14] E. Fouad, F. Ahmad, K. Abdelrahman, Optimization of Emulsion Liquid Membrane for Lead Separation from Aqueous Solutions, Engineering, Technology \& Applied Science Research 7 (2017) 2068-2072.

[15] L. Zeng, W. Wang, W. Chen, C. Bukirwa, Y. Yang, Experimental and modeling of nickel removal from sulfate solutions by emulsion liquid membrane using PC 88A, Desalination and Water Treatment 57 (2016) 11184-11194.

[16] Y.S. Ng, N.S. Jayakumar, M.A. Hashim, Performance evaluation of organic emulsion liquid membrane on phenol removal, Journal of Hazardous Materials 184 (2010) 255-260.

[17] P.F. Correia, J.M. de Carvalho, A comparison of models for 2-chlorophenol recovery from aqueous solutions by emulsion liquid membranes, Chemical engineering science 56 (2001) 5317-5325.

[18] I. Diaconu, R. Gîrdea, C. Cristea, G. Nechifor, E. Ruse, E.E. Totu, Removal and recovery of some phenolic pollutants using liquid membranes, Romanian Biotechnological Letters 15 (2010) 57025708.

[19] H.E. Mahmoud, A.A. Al-Hemiri, Minimization of Toxic Ions in Waste Water Using Emulsion Liquid Membrane Technique, Iraqi Journal of Chemical and Petroleum Engineering 11 (2010) 11-19.

[20] O. Zing-Yi, N. Othman, M. Mohamad, R. Rashid, Removal performance of lignin compound from simulated pulping wastewater using emulsion liquid membrane process, International Journal of Global Warming 6 (2014) 270-283.

[21] B. Sengupta, M.S. Bhakhar, R. Sengupta, Extraction of copper from ammoniacal solutions into emulsion liquid membranes using LIX $84 \quad \mathrm{I} \circledast$, Hydrometallurgy 89 (2007) 311-318.

[22] A. Rouhollahi, E. Zolfonoun, M. SalavatiNiasari, Effect of anionic surfactant on transport of copper (II) through liquid membrane containing a new synthesis Schiff base, Separation and purification technology 54 (2007) 28-33.

[23] Z. Ren, W. Zhang, H. Meng, Y. Liu, Y. Dai, Extraction equilibria of copper (II) with D2EHPA in kerosene from aqueous solutions in acetate buffer media, Journal of Chemical \& Engineering Data 52 (2007) 438-441.

[24] J. He, Y. Li, X. Xue, H. Ru, X. Huang, H. Yang, Extraction of Ce (IV) from sulphuric acid solution by emulsion liquid membrane using D2EHPA as carrier, RSC Advances 5 (2015) 74961-74972.

[25] M. Irannajad, Z. Afzali, H.K. Haghighi, Solvent Extraction of Copper Using TBP, D2EHPA and MIBK, Russian Journal of Non-Ferrous Metals 59 (2018) 605-611.

[26] R.A. Kumbasar, Extraction and concentration of cobalt from acidic leach solutions containing $\mathrm{Co}-\mathrm{Ni}$ by emulsion liquid membrane using TOA as extractant, Journal of Industrial and Engineering Chemistry 16 (2010) 448-454.

[27] Y.R. Abdulmajeed, C.K. Haweel, Q.J. Slaiman, REMOVAL of HEAVY METALS IONS from AQUEOUS SOLUTIONS USING BIOSORPTION onto BAMBOO, Iraqi Journal of Chemical and Petroleum Engineering 11 (2010) 23-32.

[28] A. Kusumastuti, R. Syamwil, S. Anis, Emulsion liquid membrane for textile dye removal: Stability study, AIP Conference Proceedings, AIP Publishing, 2017, pp. 020026.

[29] M. Perumal, B. Soundarajan, N. Thazhathuveettil Vengara, Extraction of $\mathrm{Cr}$ (VI) by pickering emulsion liquid membrane using amphiphilic silica nanowires (ASNWs) as a surfactant, Journal of Dispersion Science and Technology (2018) 1-10. 


\title{
إزالة أيونات النحاس من محلول مائي باستخدام تقنية الغثاء السطحي السائل
}

\author{
هدى محمد سلمان و احمد عبد محمد \\ قسم الهندسة البيئية, كلبة الهندسة, جامعة بغداد, العراق, بغداد
}

الخلاصة

يعد استخراج النحاس (Cu) من المحلول المائي باستخدام تقنية الغشاء السائل (LM) أكثر فعالية من الطرق التقليدية التي تتنج الحمأة ويجب ان ينم التخلص منها في مدافن النفايات. في هذا العمل ، قمنا بتكوين غثاء سطحي سائل (LSM) يستخدم زيت الكيروسين كمخف رئيسي للغشاء لإزالة أيونات النحاس من المحلول المائية من خلال حامض الفسفوريك ثنائي الإيثيل (2 - إيثيل هكسيل - D2EHPA - ) (كناقل). يعرض هذات الأسلوب العديد من المزايا منل الانتقائية العالية، التشغيل البسيط، منطلبات الطاقة المنخفضة، عملية الاستخراج

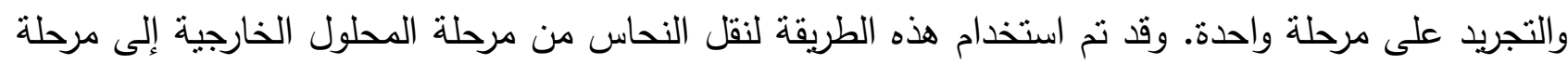

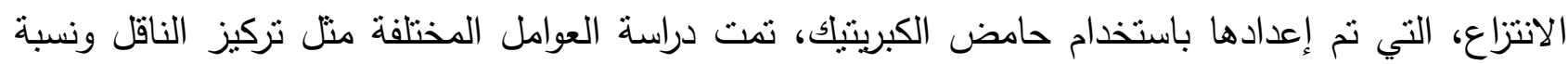
المعالجة (TR) وسرعة التحريك وتركيز النحاس الأولي. بعد الحصول على العوامل المنلى، كان نسبة استخراج النحاس 95 \% من المحلول المائي بتركيز اولي 200 ملغم لكل لتر . كلمات الدالة: النحاس، الناقل ، استخراج، المثبت، الغشاء السائل. 